\title{
Introduction to Fast Capitalism 14.1
}

\author{
Timothy W. Luke
}

This issue of Fast Capitalism is in memoriam for our colleague and friend, Ben Agger, who passed away unexpectedly on Tuesday, July 14, 2015 (Star-Telegram, 2015). As Professor of Sociology and Humanities at the University of Texas-Arlington, Ben also served as the Director of the Center for Theory, and founding editor of this journal, Fast Capitalism. Both of these projects are also based in the Sociology Program in the College of Liberal Arts at Texas-Arlington, and this journal was launched there during 2005 with issue 1.1.

During the week Ben passed away, most of the final editorial production work for 2015's issue 12.1 was already well under way. From July 14, 2015 on through the following weeks, many asked us if the journal would have a commemorative issue in recognition of Ben's life and work. I assured them that it would, although it would not necessarily be right away, given the amount of material we already had accepted for publication. Ironically, then, much of the delay in bringing out this issue for Ben is due to his successes with Fast Capitalism since its founding. During that next year, as we prepared issue 13.1 for publication in 2016, Ben's many friends, colleagues, and students, who we had asked to contribute to this issue, remained somewhat stunned by his sudden death. Not surprisingly, this reality made it more difficult than first anticipated to bring the current issue out quickly. For me, it is a tribute to Ben's good nature and gifted intellect. Few could comprehend that he was suddenly gone (Cargo, 2015), and no one wanted to let him go right away.

Slowly, this shock has worn away, and the full appreciation of Ben's rich and rewarding contributions to critical theory, digital humanities, cultural studies, methodological critique, and critical sociology more broadly have come to be appreciated. As this issue's contributors note, Ben's scholarly contributions in many fields are enduring and significant, and his multidimensional impact as an educator in many roles -- Dean, Department Head, Editor, Mentor, Professor, Teacher, and all-around University Citizen have left a tremendous legacy at the University of Texas-Arlington, University of Buffalo-SUNY, University of Waterloo in Ontario, and Bishop's University in Quebec (See Antonio, 2015: 825-827; and, Nickel, 2012: 128-154). Most of all, Ben is remembered as a generous, engaging, and brilliant individual, who daily sought to make a difference, and then made it in countless ways. I worked with him gladly for over 25 years, and feel very fortunate to have had such a friend, interlocutor, and partner for many fruitful scholarly collaborations (See Nickel, 2012: 14-41, 128-154).

After a year to eighteen months, more contributions finally did roll into the journal, and we now have this remembrance issue. Following my brief Introduction, the initial five comments by Robert L. Bing, Elisabeth Chaves, Bob Kunovich, Joshua Olsberg, and Jason E. Shelton present a range of individual thoughts about what Ben Agger meant to them, personally and professionally. The next two essays by Lukas Szrot and Mark P. Worrell are written in a comparable register, but they also develop more extended meditations on Ben Agger's career as a social theorist as well as his place in the field of sociology.

The next six articles are works either inspired by and/or written in recognition of Ben Agger's place in the larger field of critical social theory. David Arditi, the current University of Texas-Arlington-based editor of Fast Capitalism, returns to Theodor Adorno in his essay "Would Adorno Download Music? Piracy, the Recording Industry, and Reproduction Reconsidered" in which he relates the economic and social dynamics of the contemporary recorded music industry to Agger's work in cultural studies. Likewise, my contribution, "Exploring the Chaos of Commodification: From the Arcades to the Cascades with Benjamin and Leopold," also departs from Agger's critical theory-driven approach to cultural criticism as well as writers from the Frankfurt School. It focuses on Walter Benjamin's suggestive assessment of the dialectics of riches and ruination in the elaborate built urban environment 
of the Paris Arcades for critical insights into how American mountain wilderness parks might also be decoded as another variety of complex built rural environment. Playing off of the thoughts of Aldo Leopold, the midtwentieth century American environmental thinker, the essay explores how the whole Earth environment itself increasingly might be catalogued as an intricate built environment, which the Cascades Recreation Area outside of Pearisburg, Virginia well demonstrates. Robert Kirsch in his "Toward a Theory of Economic Development as a Mode of Flash Capitalism" picks up notions sparked by Agger's analyses of "fast capitalism" to ask how contemporary projects for local and regional economic development could be understood as "flash capitalism," which are organized in successive short bursts as much to buttress shaky myths about capitalist growth with media attention, expert management, and public-private capital partnerships as they are meant to create any truly lasting economic development. Much of Agger's theoretical work focused on the impact of the Internet and digital culture on postmodern capitalism. Michael A. Peters focuses on these concerns in his "Algorithmic Capitalism in the Epoch of Digital Reason," which traces the influence of cybernetic capitalism on knowledge, culture, labor, finance, and biopolitics. Doug Kellner's intense analysis, “Trump, Media Spectacle, and Authoritarian Populism," delves into the uncommon presidency of Donald J. Trump and his unending mobilization of media spectacles, which is fostering styles of governance through a dangerous new authoritarian populism in the United States. Tara Brabazon, in turn, leverages notions from Agger's thoughts on digital culture to explore the experiences of graduate-level teaching and learning in new digital environments in her essay, "5 Minutes to Hell: Time to Tell the Truth." As an academic dean, graduate supervisor, and university professor, she sees digitization, deterritorialization, and disintermediation creating new and different modes of education in her work with students at Flinders University in Australia. Scott McNall's contribution, "A Jeremiad for Ben: Things Fall Apart" also brings his appreciation of Agger's keen sociological criticism to assess life in the opening days of America's forty-fifth president, Donald J. Trump. McNall recounts how Agger himself might have interpreted the fluid rhetorical and political conditions that led to the American electorate voting in 2016 to "Make America Great Again."

The issue concludes with Stephen Turner's powerful personal and philosophical appraisal, "Ben Agger was a Blazing Intellect.” He positions Agger's multi-faceted contributions to contemporary sociology, methodological debates, and the state of sociological theory from the 1970s into the early twenty-first century. A tribute to Ben Agger's quality as a thinker, innovator, and academic in the modern research university as it morphed into a key node in "the knowledge economy," Turner's study highlights how a free, original and well-grounded intellect can resist the formalism, emptiness, and banality of normal social science simply by pushing ahead to complete one's own work to meet the best of his or her own critical measures. Turner tacitly suggests Agger's thinking and writing, like Marx or the best of the Frankfurt School, does keep to his own vision, and ready to let it stand where it rests.

\section{References}

Antonio, Robert J. 2015. "Remembering Ben Agger," Critical Sociology, Vol. 41(96), 825-827.

Cargo, Kathryn. 2015. "Ben Agger, sociology and anthropology professor, dies," The Shorthorn (July 22) See: http:// www.theshorthorn.com/news/ben-agger-sociology-andanthropology-professor-dies/article_dffab9e8-2fe9-11e5-aab0c302cdd75f7a.html

Nickel, Patricia Mooney, ed. 2012. North American Critical Theory after Postmodernism: Contemporary Dialogues. New York: Palgrave.

Star-Telegram. 2015. "Ben Agger, 1952-2015." Star-Telegram (July 22). See: http://www.legacy.com/obituaries/dfw/obituary. aspx?pid $=175317859$ 